Jurnal PG-PAUD Trunojoyo : Jurnal Pendidikan dan Pembelajaran Anak Usia Dini, Volume 6, Nomor 2, Oktober 2019, hal 91 - 100, ISSN : 2528-3553 (online), ISSN: 2407-4454 (print)

\title{
PENDIDIKAN KARAKTER MELALUI PEMBELAJARAN DI KB DEWI SARTIKA DESA BATU MAK JAGE KABUPATEN SAMBAS
}

\author{
Bayu Suratman \\ Laily Fitriani \\ Program Studi Pendidikan Islam Anak Usia Dini Universitas Islam Negeri Sunan Kalijaga Yogyakarta \\ Email:suratmanbayu9@gmail.com,lailyfitriani5@gmail.com
}

Received (Bulan Juni 2019), Accepted (Bulan Agustus 2019), Published (Bulan Oktober 2019)

\begin{abstract}
This paper describers character through learning at KB Dewi Sartika Batu Mak Jage Village, Tebas district, Sambas regency, west Kalimantan province. Based on research that the authors did, character education that was instilled by the teacher was based on the community's social and environmental condition where the students lived. Student in KB Dewi Sartika consisof tribes namely, Malay and Dayak. Planting character values vy the teacher is done through learning that is given. This article was written descriptively and departed from the qualitative research that the author did, based on the equipment and interviews carried out the teacher at KB Dewi Sartika, Batu Mak Jage Village.
\end{abstract}

\section{Keywords: Character Education, Community Social, Learning}

Abstrak: Tulisan ini mendeskripsikan pendidikan karakter melalui pembelajaran di KB Dewi Sartika Desa Batu Mak Jage Kecamatan Tebas Kabupaten Sambas Provinsi Kalimantan Barat. Berdasarkan penelitian yang penulis lakukan pendidikan karakter yang ditanamkan oleh guru berdasarkan sosial masyarakat dan kondisi lingkungan tempat tinggal siswa. Siswa yang ada di KB Dewi Sartika terdiri dari suku yaitu, Melayu dan Dayak. Penanaman nilai-nilai karakter oleh guru dilakukan melalui pembelajaran yang diberikan. Artikel ini ditulis secara deskriptif dan berangkat dari penelitian kualitatif yang penulis lakukan, berdasarkan pengamatan dan wawancara yang dilakukan kepada guru di KB Dewi Sartika Desa Batu Mak Jage.

Kata Kunci : Pendidikan Karakter, Sosial Masyarakat, Pembelajaran

\section{PENDAHULUAN}

Pendidikan anak usia merupakan langkah awal dalam menatap masa depan dalam membangun karakter seseorang. Tumbuh kembang seseorang ditentukan pada masa golden age yaitu 0-6 tahun. Abd. Rachman Assegaf dalam Mukodi (2011:iv) menyebutkan anak usia dini (umur 0 sampai 6 tahun) adalah masa emas (golden age) yang senantiasa dinamis dan tumbuh berkembang dengan pesat. Bayangan masa keemasan anak tersebut akan terbawa sampai dewasa bahkan masa tua. Pendidikan anak usia dini merupakan yang paling dasar dari membangun karakter seseorang. Sehingga didikan pada masa emas akan terbawa hingga dewasa. Mendidik anak sebaik mungkin pada usia dini merupakan wujud dari hakikat manusia dikarenakan masa emas tidak akan terulang kembali.

Membangun karakter anak sejak usia dini salah satu masalah dalam pendidikan nasional. Tidak, sedikit orangtua bahkan juga guru tidak mengetahui bahwasanya pendidikan anak usia dini sangat penting. Selain itu, pelaksanaan pendidikan anak usia dini juga masih banyak diterapkan bahwasanya anak usia dini berada PAUD datang untuk belajar. Bahkan, orangtua berharap anaknya dapat membaca dan menulis ketika dimasukan di lembaga PAUD. Padahal, pada dasarnya anak usia dini hanya usia bermain bukan membaca dan menulis. Melainkan membangun karakter anak sejak dari usia dini melalui bermain dan tahap perkembangan anak.

Dapat di mafhumi bahwa usia emas sangat menentukan masa depan seorang anak jika mendapatkan didikan yang baik dari sejak kecil maka akan berdampak pada saat dewasa sehingga menjadi manusia yang seutuhnya. Begitu juga sebaliknya apabila pada masa emas mendapatkan didikan yang kurang baik maka akan berdampak buruk kedepannya. Berdasarkan ini, salah satu peran yang dapat menjadikan manusia seutuhnya adalah pendidikan karakter sejak usia dini melalui kurikulum dan pembelajaran yang dilakukan di PAUD. Peran karakter tidak dapat disisihkan dalam permasalaham kualitas manusia. Hal ini sejalan dengan pandangan Novan Ardy Wiyani (2013:13) fungsi dan tujuan pendidikan terdapat proses transformasi 
92 Jurnal PG-PAUD Trunojoyo : Jurnal Pendidikan dan Pembelajaran Anak Usia Dini, Volume 6, Nomor 2, Oktober 2019, hal 91 - 100, ISSN : 2528-3553 (online), ISSN: 2407-4454 (print)

pengetahuan yang mewujudkan peserta didik yang berpengetahuan dan transformasi nilai menghasilkan peserta didik yang berkarakter. Luluk Asmawati (2014:27) Peserta didik anak usia dini adalah anak yang berusia 0-6 tahun. Peserta didik anak usia dini ditinjau dari aspek-aspek perkembangannya merupakan perentang perkembangan manusia secara keseluruhan. Jika dilihat dari penjelasan Marhumah dalam Mahmud Arif,dkk (2013:7576) mengatakan bahwa tumbuh kembang anak hendaknya menjadi perhatian utama bagi pendidikan, anak usia dini perlu diarahkan pada peletakkan dasar yang tepat bagi pertumbuhan dan perkembangan maksimal baik dari aspek fisik, psikis sosial dan emosional.

Pendidikan menjadi pembahasan yang paling tinggi terlebih terhadap kualitas pendidikan yang ada sehingga telah menjadi bagian penting dalam kehidupan sosial. Sehingga pendidikan merupakan sarana paling efefktif untuk membangun karakter (character building).(Hamruni \& Kurniawan, 2018:139). Sarana tersebut adalah lembaga pendidikan yang mampu mengoptimalkan potensi-potensi di dalam diri sejak anak usia dini setiap orang membutuhkan pendidikan. Dalam keluarga membutuhkan peran orang tua, dalam sekolah membutuhkan peran guru, dan dalam masyarakat membutuhkan peran masyarakat yang membimbing dan mengajarkan untuk mengajarkan kebiasaan berpikir secara benar dan bertingkah laku secara mandiri dan mampu mengendalikan dorongan alamiah.(Siti Musdah \& Aini, 2013:110). Hal inilah yang membuat pendidikan sangat penting dalam membangun bangsa. Pendidikan tidak hanya semata-mata mentransferkan ilmu pengetahuan kepada peserta didik tetapi menanamkan nilai-nilai karakter kepada peserta didik. Jika dilihat dari pengertian karakter dalam pandangan Prayitno \& Belferik manulang (2011:47) karakter adalah sifat pribadi yang relatif stabil pada diri individu yang menjadi landasan bagi penampilan perilaku yang standar nilai dan norma yang tinggi. Lebih lanjut, Prayitno \& Belferik Manulang menekankan ada empat komponen dalam karakter:

1. Relatif stabil: suatu kondisi yang apabila telah terbentuk akan tidak mudah diubah.

2. Landasan: kekuatan yang pengaruhnya sangat besar/ dominan dan menyeluruh terhadap hal-hal yang terkait langsung dengan kekuatan yang dimaksud.

3. Penampilan perilaku: aktivitas individu atau kelompok dalam bidang dan wilayah (setting) kehidupan.

4. Standar nilai/norma: kondisi yang mengacu kepada kaidah-kaidah agama, ilu dan teknologi, hukum, adat, dan kebiaaan, yang tercermin dalam perilaku sehari-hari dengan indikator iman dan takwa, pengendalian diri, serta disiplin, kerja keras, dan ulet, bertanggung jawab dan jujur, membela kebenaran, kepatutan, kesopanan dan kesantunan, ketaatan pada peraturan, loyal, demokratis, sikap kebersamaan, musyawarah, dan gotong royong, toleran, tertib, damai, dan anti kekerasan, hemat dan konsisten.

Karakter dari segi bahasa diambil dari bahasa Inggris character, yang juga berasal dari bahasa Yunani character. Pada mulanya kata karakter digunakan untuk menandai hal yang mengesankan dari koin (keping uang). Secara umum istilah character digunakan untuk mengartikan hal yang berbeda antara satu hal dengan yang lain dan akhirnya digunakan untuk menyebut kesamaan kualitas pada tiap orang orang yang membedakan dengan kualitas lainnya. Sedangkan dalam istilah modern karakter ditekankan pada perbedaan dan individualitas yang cenderung menyamakan istilah karakter dengan personalitas. Personalitas atau kepribadian dapat dipahami sebagai organisasi dinamis pada individu tempat sistem psikofisikal menentukan penyesuian unik terhadap lingkungannya. Kepribadian juga merupakan tingkah laku yang bisa dilihat dari hasil kondisi dan struktur situasi psikologis.(Fatchul Mu'in, 2016:162).

Konsep lain yang berhubungan dengan karakter ialah paedagogie dan paedogogiek. Paedagogie artinya pendidikan sedangkan paedagogiek berarti ilmu pendidikan.(M.Mahbubi,2012:38). Setidaknya karakter memiliki tiga bagian yang saling berhubungan: pengetahuan moral, perasaan moral, dan perilaku moral. Terlebih, karakter yang baik terdiri dari mengetahui hal yang baik, menginginkan hal yang baik, dan melakukan hal yang baik kebiasaan dalam cara berpikir, kebiasaan yang dalam hati, dan kebiasaan dalam tindakan.(Lickona,2013:82). Azalinya, karakter sangat erat kaitannya dengan pendidikan hal itu yang mendasari 
Jurnal PG-PAUD Trunojoyo : Jurnal Pendidikan dan Pembelajaran Anak Usia Dini, Volume 6, Nomor 2, Oktober 2019, hal $91-100$, ISSN : 2528-3553 (online), ISSN: 2407-4454 (print)

pendidikan karakter untuk diterapkan di sekolah terlebih pendidikan anak usia dini. Hakikatnya pendidikan karakter adalah upaya yang dilakukan secara sistematis dalam mendorong peserta didik dalam memahami nilai-nilai perilaku sehingga peserta didik dalam bersikap dan bertindak.(Nadlifah, 2015:54). Sedangkan menurut Maemmonah (2015:45) pendidikan karakter merupakan suatu sistem penanaman nilai karakter kepada peserta didik yang meliputi komponen pengetahuan, kesadaran peserta didik yang meliputi komponen pengetahuan, kesadaran atau kemauan, dan tindakan untuk melaksanakan tindakan. Jadi, pendidikan karakter merupakan proses penanaman nilainilai perilaku pesera didik melalui pengetahuan, kesadaran dan kemauan peserta didik dalam berprilaku yang sesuai dengan dengan nilai-nilai karakter.

Pendidikan karater bukan haya semata-mata ditanamkan kepada peserta didik mealui teoritik melainkan pembiasaanpembiasaan yang dilakukan oleh guru di sekolah. Pembiasaan-pembiasaan bisa dilakukan melalui hal-hal yang kecil di dalam pembelajaran. Hal itu relevan dalam pandangan Nadlifah (2017:28) pendidikan karakter harus dilakukan secara holistik dalam program sekolah dan tidak boleh dilakukan parsial. Lingkungan sekolah menjadi tempat yang paling tepat dalam pertumbuhan karakter anak. Setiap kegiatan yang dilakukan sekolah harus diintegrasikan dalam program pendidikan secara holistik terhadap program sekolah.

Pendidikan anak usia dini sangat diperlukan guna menciptakan manusia yang unggul dan bersaing serta berakhlak di masa yang akan datang. Memberikan pendidikan bagi anak usia dini negara menyelenggarakan dan memfasilitasi pendidikan anak usia dini (PAUD) dengan diberlakukannya UU Nomor 20 tahun 2003 maka PAUD menjadi bagian dari sistem pendidikan yang ada di Indonesia. Menurut Luluk Asmawati (2014:27) Peserta didik anak usia dini adalah anak yang berusia 0-6 tahun. Peserta didik anak usia dini ditinjau dari aspek-aspek perkembangannya merupakan perentang perkembangan manusia secara keseluruhan. Hal itu sejalan dengan hakikat anak usia dini dalam Undang-Undang Sistem Pendidikan Nasional No.20 Tahun 2003 adalah kelompok manusia yang berusia 0 sampai 6 tahun.(Yeni Racmawati \& Kurniati, 2010:6).

Pendidikan anak usia dini tidak hanya berpaku pada satu aspek melainkan banyak aspek-aspek lain yang harus diperhatikan dalam memberikan pendidikan anak usia dini. Menurut Mardiyati (2015:40) Pendidikan anak usia dini merupakan salah satu bentuk penyelenggaraan pendidikan yang menitikberatkan pada peletakan dasar ke arah pertumbuhan dan perkembangan fisik (koordinasi motorik halus dan kasar), kecerdasan (daya pikir, daya cipta, kecerdasan emosi, kecerdasan spiritual), sosio emosional (sikap dan perilaku serta agama) bahasa dan komunikasi, sesuai dengan keunikan dan tahap-tahap perkembangan yang dilalui oleh anak usia dini.

Pendidikan anak usia dini sangat penting bagi perkembangan anak kedepannya, karena usia dini merupakan dasar pertama anak dalam melangsungkan kehidupan ditahap selanjutnya. Anak yang mendapat kasih sayang sejak usia dini sesuai dengan tahap perkembangan akan berdampak kepada anak baik dilingkungan keluarga, sekolah dan masyarakat. Pentingnya pendidikan karakter di era saat ini masih menjadi pembahasan yang sering dibincangkan di semua lembaga pendidikan. Seolah-olah ada yang salah dari penerapan pendidikan karakter yang ada di Indonesia. Seringkali, seorang pendidik terjebak dalam istilah karakter yang dapat dibentuk. Pada dasarnya karakter hanya dapat dibangun atau ditanamkan kepada anak. Jika mengutip pendapat Masnur Muslich (2014:67) pendidikan karakter pendidikan yang mengarah pada pencapaian pembentukan karakter dan akhlak mulia peserta didik secara utuh, terpadu, dan seimbang. Pendidikan karakter anak dapat menggunakan pengetahuannya ke dalam nilai-nilai karakter dan akhlak mulia sehingga terwujud dalam perilaku sehari-hari. Pendidikan karakter anak usia dini merupakan pendidikan yang menanamkan nilai-nilai karakter kepada peserta didik, sehingga mereka akan memiliki karakter untuk dipraktikkan dalam kehidupannya dalam berkeluarga, bermasyarakat, dan warga negara. (Iswantiningtyas \& Wulansari, 2018:200)

Agus Wibowo dalam Syamsul Kurniawan (2013:31) mendefinisikan pendidikan karakter sebagai pendidikan yang menanamkan dan 
94 Jurnal PG-PAUD Trunojoyo : Jurnal Pendidikan dan Pembelajaran Anak Usia Dini, Volume 6, Nomor 2, Oktober 2019, hal 91 - 100, ISSN : 2528-3553 (online), ISSN: 2407-4454 (print)

mengembangkan karakter-karakter luhur kepada anak didik sehingga mereka memiliki karakter luhur kepada anak didik sehingga memiliki karakter luhur tersebut, menerapkan dan mempraktikkan dalam kehidupannya, entah dalam keluarga, sebagai anggota masyarakat dan warga negara. Pada konteks ini, apabila dikaitkan dengan tumbuh kembang anak usia dini ada beberapa manfaat dari pendidikan anak usia dini, antara lain: potensi dapat berkembang dengan maksimal; anak dapat bersosialisasi dengan dunia sekitarnya; mengajarkan anak norma-norma dan kedisiplinan; anak dapat menikmati masa bermainnya dengan puas; membantu orang tua memenuhi kebutuhan anak. (M.Fadillah, 2018:12-14)

Karakter yang ditanamkan kepada anak telah menjadi penanda dan ciri khas dari siswa tersebut sebagai dari anggota di sekolah dan masyarakat setempat. Sehingga karakter yang ditanamkan atau dibangun kepada siswa harus sesuai dengan kondisi sosial masyarakat setempat dalam hal ini telah menjadi habitus. Mohammad Adib (2012:101) menyebutkan habitus dapat terarah kepada tujuan dan hasil tindakan tertentu tetapi tanpa ada maksud secara sadar dalam mencapai hasil tersebut. Lickona (2012:45) menyebutkan karakter terdiri kebiasaan-kebiasaan. Kebiasaankebiasaan yang dibentuk semasa kanak-kanak dan remaja kerap bertahan hingga dewasa. Dalam istilah Sudaryanti (2012:14) karakter bukan gejala sesaat melainkan tindakan yang konsisten muncul baik secara batiniah maupun rohaniah. Karakter ini disebut sebagai karakter moral atau identitas moral. Karakter mengacu pada kebiasaan berpikir, berperasaan, bersikap, berbuat yang memberi bentuk tekstur dan motivasi kehidupan seseorang.

Hal itu relevan dengan pandangan Hidayat dalam Inawati (2017:54) anak usia dini dasarnya memerlukan bantuan dalam beberapa hal: seperti pembentukan karakter (formation of character), pembentukan kepribadian (shaping of personality), dan perkembangan sosial (social development). Lebih lanjut, Inawati menjelaskan pembentukan karakter dalam rangka pengembangan moralitas seorang anak dipengaruhi oleh lingkungan sekolah. Akan tetapi, pendidikan karakter yang dilakukan di sekolah sudah sepatutnya dibantu oleh pihak orang tua agar ada kesinambungan antara pendidikan karakter di sekolah dengan didikan di rumah. Lickona (2013:48) keluarga merupakan sumber pendidikan moral yang paling utama. Terlebih, orang tua adalah guru pertama dalam memberikan pendidikan moral kepada anak dan paling besar berpengaruh dalam perkembangan moral anak. Hubungan orang tua dan anak dipenuhi dengan perbedaan terlebih dalam emosi, menyebabkan anak merasakan dicintai dan dihargai atau tidak dicintai dan dikesampingkan.

Sudah sepatutnya, pendidikan karakter yang diberikan kepada anak usia dini harus sesuai dengan kebutuhan dan perkembangan anak. Sekolah merupakan faktor penting dalam keberhasilan menjalankan pendidikan karakter. Akan tetapi, orang tua merupakan usnur utama dalam membangun karakter seorang anak karena baik dari segi waktu dan kedekatan emosi anak dan orang tua suatu yang tidak dapat dipisahkan. Karakter anak merupakan cerminan dari didikan yang diberikan oleh orang tua dirumah. Azalinya, sekolah dan orang tua harus saling membantu dalam membangun karakter anak. Tanpa, adanya kerjasama antara orangtua dan sekolah maka pendidikan karakter yang ditanamkan kepada anak tidak akan berhasil.

Berdasarkan ini, pendidikan karakter mengaktifkan wujud dari tingkah laku yang diterapkan dalam kehidupan sehari-hari lewat didikan yang diberikan khususnya di lembaga pendidikan anak usia dini. KB Dewi Sartika salah satu lembaga PAUD yang melakukan binaan terhadap anak usia dini melalui nilainilai budaya yang berlaku pada masyarakat setempat. KB Dewi Sartika terletak di Dusun Pangkalan Kongsi desa Batu Mak Jage kecamatan Tebas Kabupaten Sambas. Dusun Pangkalan Kongsi mempunyai dua suku yang berbeda yaitu, Dayak dan Melayu. Sangat sedikit lembaga PAUD yang berdiri antar suku berbeda terlebih masyarakat yang berbeda hidup secara rukun dan damai.

Penelitian tentang pendidikan karakter di lembaga PAUD Kabupaten Sambas masih sedikit sekali ditemukan. Setidaknya penelitian tentang pendidikan anak usia dini di Sambas telah dilakukan oleh sejumlah peneliti, seperti, Syamsul Kurniawan dengan judul "Pantang Larang in the sepinggan Vilagge Community from the perspective of Character Education". Selain itu, penelitian yang pernah dilakukan di PAUD di kabupaten Sambas, Martin dengan judul analisis kecerdasan interpersonal anak usia dini dan implementasinya dalam 
Jurnal PG-PAUD Trunojoyo : Jurnal Pendidikan dan Pembelajaran Anak Usia Dini, Volume 6, Nomor 2, Oktober 2019, hal $91-100$, ISSN : 2528-3553 (online), ISSN: 2407-4454 (print)

bimbingan dan konseling. Kedua, peneliti tersebut hanya terfokus kepada pendidikan karakter dalam kearifan lokal yang dijalankan oleh masyarakat Sambas. Sedangkan jurnal Martin hanya berfokus kepada kecerdasan anak yang ada di salah satu lembaga PAUD di Kabupaten Sambas. Sementara fokus artikel ini adalah tentang pendidikan karakter melalui pembelajaran di KB Dewi Sartika Desa Batu Mak Jage Kabupaten Sambas.

\section{METODE}

Tulisan ini berangkat dari sebuah penelitian kualitatif di mana datanya diperoleh dari wawancara dan observasi di lokasi penelitian dan penelitian ini dilakukan melalui pendekatan deskriptif. Fokus artikel ini adalah pendidikan karakter melalui pembelajaran di KB Dewi Sartika Desa Batu Mak Jage Kabupaten Sambas. Artikel ini mendeskripsikan bagaimana pendidikan karakter yang diberikan di KB Dewi Sartika berdasarkan latar belakang anak, baik orangtua maupun sosial masyarakat setempat melalui pembelajaran yang dilakukan oleh guru.

\section{HASIL DAN PEMBAHASAN Hasil}

Selama didirikannya PAUD Dewi Sartika setidaknya sekitar 159 peserta didik yang telah menempuh pendidikan anak usia dini di PAUD Dewi Sartika, dengan rincian seperti pada tabel 1 berikut.

Berdasarkan latar belakang orangtua dari murid KB Dewi Sartika mayoritas petani dan pekebun. Bahkan, pada murid pada tahun 2018 dari dari 25 orang hanya 1 orang yang bekerja sebagai swasta sedangkan 24 yang lain bekerja sebagai petani dan pekebun. Orangtua yang bekerja sebagai petani dan pekebun ialah petani padi dan pekebun sawit.(Wawancara dengan Ibu Yusniarti dan Ibu Pariza pada tanggal 20 Januari 2019).

Jika dikaitkan antara nilai satu dengan yang lain maka nilai religi menjadi nilai tertinggi dan menjadi acuan nilai-nilai yang lain. Hal ini dapat dilihat pada gambar 1.

Tabel 1

Data Siswa KB Dewi Sartika 2010-2019

\begin{tabular}{cccc}
\hline Tahun & $\begin{array}{c}\text { Siswa } \\
\text { Melayu }\end{array}$ & $\begin{array}{c}\text { Siswa } \\
\text { Dayak }\end{array}$ & Jumlah \\
\hline 2010 & 10 & 0 & 10 \\
2011 & 12 & 0 & 12 \\
2012 & 11 & 4 & 15 \\
2013 & 8 & 5 & 13 \\
2014 & 10 & 1 & 11 \\
2015 & 24 & 4 & 28 \\
2016 & 23 & 5 & 28 \\
2017 & 12 & 5 & 17 \\
2018 & 21 & 4 & 25 \\
\hline & & & \\
Jumlah & $\mathbf{1 3 1}$ & $\mathbf{2 8}$ & $\mathbf{1 5 9}$ \\
\hline
\end{tabular}

Sumber:Data KB Dewi Sartika Desa Batu Mak

Jage 2010-2019

Tabel 2.

Nilai Karakter yang Ditanamkan di KB Dewi

Sartika

\begin{tabular}{|c|c|}
\hline Nilai Karakter & Deskripsi Kegiatan \\
\hline Religi & $\begin{array}{l}\text { Anak-anak berdoa setiap mulai } \\
\text { kegiatan berdasarkan ajaran agama } \\
\text { yang dianut. Belajar beribadah yang } \\
\text { diajarkan oleh guru. }\end{array}$ \\
\hline Jujur & $\begin{array}{l}\text { Anak diajarkan selalu berprilaku } \\
\text { jujur dalam kegiatan yang dilakukan } \\
\text { oleh guru }\end{array}$ \\
\hline $\begin{array}{l}\text { Peduli } \\
\text { Lingkungan }\end{array}$ & $\begin{array}{l}\text { Anak diajak pergi ke kebun, sawah, } \\
\text { di sekitar lingkunga sekolah dan } \\
\text { selalu diajarkan membuang sampah } \\
\text { pada tempatnya dan melakukan } \\
\text { penanaman pohon bersama-sama. }\end{array}$ \\
\hline Toleransi & $\begin{array}{l}\text { Anak selalu diajarkan menghargai } \\
\text { temannya yang berbeda suku dan } \\
\text { agama. }\end{array}$ \\
\hline Peduli Sosial & $\begin{array}{l}\text { Anak mempunyai sikap sosial yang } \\
\text { tinggi seperti saling membantu dan } \\
\text { anak dibawa berkunjung kerumah } \\
\text { teman-temannya }\end{array}$ \\
\hline Bersahabat & $\begin{array}{lll}\text { Anak selalu dibiasakan } & \text { selalu } \\
\text { bergaul sesama teman } & \text { tanpa } \\
\text { memandang suku, agama, dll. } & \end{array}$ \\
\hline $\begin{array}{l}\text { Semangat } \\
\text { kebangsaan }\end{array}$ & $\begin{array}{l}\text { Anak selau ditanamkan rasa } \\
\text { nasionalisme melalui simbol-simbol } \\
\text { negara, misalnya budaya. }\end{array}$ \\
\hline Kerja sama & $\begin{array}{l}\text { Anak selalu ditanamkan mempunyai } \\
\text { sifat kerja antar siswa baik dalam } \\
\text { belajar maupun bermain }\end{array}$ \\
\hline Rasa ingin tahu & $\begin{array}{l}\text { Guru selalu memberikan anak } \\
\text { kesempatan bertanya }\end{array}$ \\
\hline Disiplin & $\begin{array}{l}\text { Anak selalu diajarkan untuk selalu } \\
\text { bersikap disiplin seperti, patuh dan } \\
\text { tertib dalam bermain dan belajar }\end{array}$ \\
\hline Demokratis & $\begin{array}{l}\text { Guru selalu mengajarkan persamaan } \\
\text { antar anak baik hak dan tanggung } \\
\text { jawab anak di KB Dewi Sartika } \\
\text { tanpa diskriminasi }\end{array}$ \\
\hline \multicolumn{2}{|c|}{$\begin{array}{l}\text { Sumber: Hasil wawancara dengan Ibu } \\
\text { Pariza dan Ibu Yusniarti (20 Januari } \\
\text { 2019) }\end{array}$} \\
\hline
\end{tabular}


96 Jurnal PG-PAUD Trunojoyo : Jurnal Pendidikan dan Pembelajaran Anak Usia Dini, Volume 6, Nomor 2, Oktober 2019, hal 91 - 100, ISSN : 2528-3553 (online), ISSN: 2407-4454 (print)

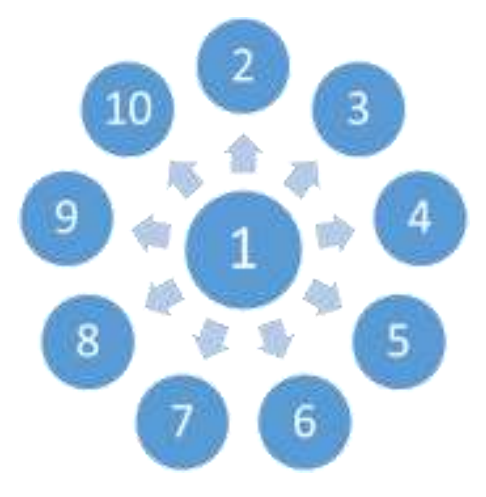

Gambar 1. Nilai-Nilai Pendidikan Karakter Yang Ada di KB Dewi Sartika

\section{Pembahasan \\ Kondisi Objektif Masyarakat dan KB Dewi Sartika di Desa Batu Makjage Kabupaten Sambas}

KB Dewi Sartika merupakan lembaga pendidikan anak usia dini yang terletak di desa Batu Mak Jage kecamatan Tebas Kabupaten Sambas Provinsi Kalimantan Barat. Untuk sampai di desa Batu Makjage dari pasar Tebas kurang lebih memerlukan waktu 40 menit. KB Dewi Sartika berada di dusun Pangkalan Kongsi dan berada diseberang kantor desa Batu Mak Jage sehingga menuju KB Dewi Sartika harus menyeberangi sungai dengan menggunakan sampan. Dusun Pangkalan Kongsi tediri dua etnis yaitu, Melayu dan Dayak. Sebelah hulu dusun Pangkalan Kongsi atau masyarakat menyebutnya dengan Mentibar dihuni oleh Suku Melayu. Sedangkan sebelah hilir dihuni oleh mayoritas Dayak walaupun ada beberapa rumah suku Melayu.

Menurut Hermansyah (2015:1) menyebut Melayu sebagai penganut ajaran Islam. Selain itu, Islam sebagai penanda identitas kemelayuan seseorang. Melayu dan Islam tidak dapat dipisahkan karena telah menjadi identitas dari Melayu. Hal itu sesuai dengan pendapat Yusriadi (2015:97) agama Islam merupakan bagian penting dari identitas Melayu dan agama Islam merupakan tanda bahwa mereka sebagai Melayu. Sedangkan suku Dayak yang ada di Desa Batu Mak Jage beragama Kristen. Meski berbeda suku maupun agama tidak menyurutkan masyarakat yang ada di dusun Pangkalan Kongsi untuk saling hidup berdampingan, rukun, dan damai. Jika dilihat dari sejarahnya masih belum pernah ditemukan konflik yang terjadi antar dua masyarakat yang berbeda khususnya di Desa Batu Mak Jage. Hidup rukun dan damai dapat dilihat dari keseharian masyarakat bahkan dalam acara perkawinan juga masyarakat Melayu dan Dayak yang ada di dusun Pangkalan Kongsi saling mengundang dalam acara perkawinan. Jika masyarakat Dayak mengadakan acara pernikahan maka masyarakat Melayu juga diundang. Akan tetapi, untuk makan dan memasak hidangan makanan dilakukan dan dihidangkan dirumah orang Melayu dekat dengan rumah masyarakat Dayak yang mengadakan acara pernikahan. Jika masyarakat Melayu mengadakan acara pernikahan maka masyarakat Dayak juga ikut membantu masyarakat Melayu dalam melaksanakan kegiatan acara pernikahan. Keakraban masyarakat juga terlihat dari kegiatan gotong royong, misalnya: membangun jalan, jembatan, membersihkan lingkungan, sungai, dan lain-lain.

Keakraban antar masyarakat baik Melayu dan Dayak juga sangat terlihat di KB Dewi Sartika Batu Mak Jage. Para guru yang ada di KB Dewi Sartika Batu Mak Jage tidak membeda-bedakan baik murid yang berasal dari suku Melayu maupun murid dari suku Dayak. KB Dewi Sartika saat ini mempunyai 2 tenaga didik, yaitu: Ibu Pariza dan Ibu Yusniarti sedangkan kepala Dewi Sartika dijabat oleh Bapak Ichsani, S.Pd. KB Dewi Sartika didirikan pada 22 Desember 2009 dan diputuskan izin oleh kepala dinas pendidikan kabupaten Sambas bapak Nurpinarto pada tanggal 14 Januari 2010. Kegiatan pembelajaran PAUD Dewi Sartika dilaksanakan empat hari dalam satu minggu yaitu mulai hari Senin sampai dengan Kamis. Waktu selama kegiatan pembelajaran Pendidikan Anak Usia Dini dari jam 07.00 09.00 WIB. Berdirinya PAUD Dewi Sartika di Desa Batu Makjage Kecamatan Tebas tidak terlepas dari dukungan: bupati dan wakil bupati Sambas, Dinas Pendidikan kabupaten Sambas, Camat Tebas, UPT Dinas pendidikan kecamatan Tebas, pemerintahan desa Batu Makjage, masyarakat desa Batu Makjage yang memiliki kesadaran akan pendidikan anak usia dini, pengelola dan tenaga didik, peserta didik, lokasi dan tempat yang tersedia di desa Batu Makjage. (Wawancara dengan Ibu Yusniarti dan Ibu Pariza pada tanggal 20 Januari 2019).

Sedangkan latar belakang orangtua dari murid KB Dewi Sartika mayoritas petani dan pekebun. Bahkan, pada murid pada tahun 2018 dari dari 25 orang hanya 1 orang yang bekerja sebagai swasta sedangkan 24 yang lain bekerja 
Jurnal PG-PAUD Trunojoyo : Jurnal Pendidikan dan Pembelajaran Anak Usia Dini, Volume 6, Nomor 2, Oktober 2019, hal $91-100$, ISSN : 2528-3553 (online), ISSN: 2407-4454 (print)

sebagai petani dan pekebun. Orangtua yang bekerja sebagai petani dan pekebun ialah petani padi dan pekebun sawit.(Wawancara dengan Ibu Yusniarti dan Ibu Pariza pada tanggal 20 Januari 2019).

Jika dilihat dari pekerjaan orangtua murid sebagai petani dan pekebun hal itu sangat wajar karena masyarakat kabupaten Sambas mayoritas bekerja sebagai petani padi. (Syamsul Kurniawan \& Suratman, 2018:53). Selain mendidik anak dirumah orangtua murid juga bekerja di sawah pada pagi dan sore hari. Sehingga KB Dewi Sartika memberikan penghargaan kepada orangtua murid melalui piagam penghargaan ketika pelepasan murid kepada orang tua. Penghargaan yangdiberikan oleh guru kepada orangtua merupakan apresiasi sekolah karena walaupun dalam keadaan sibuk orangtua masih dapat meluangkan waktu untuk mendidik anak khususnya di rumah.

\section{Nilai-Nilai Karakter di KB Dewi Sartika Desa Batu Mak Jage}

Berdasarkan pengamatan dan hasil wawacara yang dilakukan di KB Dewi Sartika Desa Batu Mak Jage memberikan pembelajaran kepada anak usia dini melalui pengenalan alam secara langsung, seperti berkunjung ke sawah, kebun dan lingkungan sekitar sekolah. nilai-nilai karakter menurut Agus Wibowo setidaknya ada 35 nilai, yaitu: Religi, Jujur, Toleransi, Disiplin, Kerja keras, Kreatif, Mandiri, Demokratis, Rasa ingin tahu, Semangat kebangsaan, Cinta tanah air, Menghargai prestasi, Bersahabat, komunikasi, Cinta damai, Gemar membaca, Peduli lingkungan, Peduli sosial, Tanggung jawab, Mandiri, Kreatif, Berani mengambil resiko, Berorientasi pada tindakan, Kepemimpinan, Kerja keras, Jujur, Disiplin, Inovatif, Tanggung jawab, Kerja sama, Pantang menyerah (ulet), Komitmen, Realistis, Rasa ingin tahu, Komunikatif, Motivasi kuat untuk sukses. (Agus Wibowo, 2017:71-73). Nilai karakter menurut Agus Wibowo tersebut diuraikan melalui deskripsi penanaman nilai karakter yang dilakukan di KB Dewi Sartika Desa Batu Mak Jage. Setidaknya ada beberapa karakter yang ditanamkan oleh guru di KB Dewi Sartika Desa Batu Mak Jage dalam proses pembelajaran berdasarkan hasil wawancara dengan Ibu Yusniarti dan Ibu Pariza.
Secara umum, tujuan pendidikan anak usia dini (PAUD) yaitu memberikan stimulasi atau rangsangan bagi perkembangan potensi anak usia dini sehingga bertumbuh dan berkembang keimanan, ketaqwaaan pada Tuhan Yang Maha Esa, berakhlaq mulia, sehat, berilmu, cakap, kritis, kreatif, inovatif, mandiri, percaya diri, dan menjadi warga negara yang demokratis dan bertanggung jawab.(Suyadi\& Maulidya Ulfa,2013:19). Hal ini relevan dengan pandangan Agus Wibowo (2017:48) ruang lingkup kurikulum di TK dan RA, hendaknya diarahkan pada aspek perkembangan anak usia dini, di antaranya: moral dan nilai-nilai agama; sosial, emosional dan kemandirian; kemampuan berbahasa; kognitif; fisik/motorik; dan seni budaya.

Pendidikan anak usia dini yang dilaksanakan di KB Dewi Sartika mempunyai pengaruh besar terhadap keberhasilan pendidikan dan perkembangan kehidupan masyarakat Desa Batu Mak Jage. Pendidikan yang tepat akan menjadi dasar anak usia dini dalam menempuh kehidupan selanjutnya atau pada masa remaja dan dewasa. Dalam hal ini, memberikan pendidikan yang sesuai perkembangan anak usia dini dan penanaman nilai karakter dapat dibangun melalui pendidikan khususnya di KB Dewi Sartika. Selain itu, RPP yang dirancang oleh guru juga menjadi landasan dalam proses pendidikan karakter yang dilakukan di sekolah khususnya di KB Dewi Sartika. Menurut Zulhijrah (2015:126) Rencana Pelaksanaan Pembelajaran (RPP) juga merupakan bagian dari perencanaan pendidikan karakter di sekolah yang merupakan rencana pendek dalam memproyeksikan karakter yang ditanamkan kepada peserta didik.

Berdasarkan hasil wawancara yang dilakukan setidaknya ada beberapa tema dalam rencana pelaksanaan pembelajaran (RPP), berikut ini tema-tema yang ada di KB Dewi Sartika, yaitu: alam semesta, tanah airku, alat, komunikasi, pekerjaan, rekreasi, tanaman, binatang, kebutuhanku, lingkunganku, diri sendiri. Dari tema yang ada selanjutnya terdapat sub tema, diantaranya: air, daerah tempat tinggalku, negaraku, non elektronik, elektronik, TNI/Polisi, nelayan, petani, guru, kendaraan udara, kendaraan laut, kendaraan darat, tempat rekreasi,tanaman obat-obatan (apotik hidup), sayuran, buah, bunga, binatang bersayap, binatang hidup di air, binatang 
98 Jurnal PG-PAUD Trunojoyo : Jurnal Pendidikan dan Pembelajaran Anak Usia Dini, Volume 6, Nomor 2, Oktober 2019, hal 91 - 100, ISSN : 2528-3553 (online), ISSN: 2407-4454 (print)

berkaki empat, unggas, kebersihan dan kesehatan, pakaian, makanan dan minuman, keluargaku, sekolah, rumahku, kesukaan ku, anggota tubuh, panca indra, identitas diri. Tema yang ada selanjutnya dikembangkan menjadi sub-sub tema dan menjadi bahan guru dalam pelaksanaan pembelajaran.

Selain belajar didalam kelas para guru juga membawa siswa bermain diluar kelas seperti, bermain di perkebunan masyarakat yang ada di sekitar KB Dewi Sartika. Pembelajaran yang dilakukan tergantung dari tema yang ada di RPP. Jika dilihat dari lokasi yang ada di KB Dewi Sartika dan mayoritas masyarakat sebagai petani padi maka memperkenalkan kepada anak-anak tentang sawah dan pekerjaan petani merupakan bentuk dari guru bahwasanya pekerjaan petani merupakan pekerjaan mulia. Selain itu, membawa anak ke sawah dan kebun juga bentuk guru untuk mengenalkan lingkungan. Sehingga dari sejak usia dini siswa telah diajarkan untuk menjaga lingkungan agar tidak tercemar. Seperti yang diketahui lokasi KB Dewi Sartika juga tiak terlalu jauh dari sungai dan tidak sedikit siswa yang sudah panai berenang. Selain itu, guru juga mengajak anakanak bermain kerumah siswa yang ada di sekitar KB Dewi Sartika.

Selain penanaman nilai karakter religi nilai peduli lingkungan salah satu paling sering ditanamkan oleh guru kepada siswa. Seperti yang diketahui kepedulian terhadap lingkungan di Indonesia masih sangat rendah sehingga guru KB Dewi Sartika berharap melalui penanaman nilai karakter peduli lingkungan siswa dapat mencintai dan menjaga lingkungan dari pencemaran, seperti: membuang sampah ke sungai, menebang pohon secara liar, membakar hutan, dan lainlain. Melalui nilai karakter peduli lingkungan siswa dapat melihat para orang tuanya dalam mengelola lingkungan sehingga menjadi sebuah profesi. Pengenalan budaya setempat juga menjadi fokus guru di KB Dewi Sartika sehingga anak dapat mencintai daerah tempat siswa tingga dan menumbuhkan rasa nasionalisme anak sejak usia dini. Setidaknya, penanaman nilai karakter yang dilakukan di KB Dewi Sartika Desa Batu Mak Jage telah diberikan berdasarkan pertimbangan kondisi sosial dan kondisi lingkungan masyarakat tempat tinggal siswa itu sendiri. Penanaman nilai karakter mealui pembelajaran di $\mathrm{KB}$ Dewi Sartika relevan dengan Lickona
(2013:74) bahwa nilai yang sebaiknya diajarkan di sekolah adalah kejujuran, keadilan, toleransi, kebijaksanaan, disiplin diri, tolong menolong, peduli sesama, kerja sama, keberanian, dan sikap demokratis. Nilai tersebut merupakan bentuk rasa hormat dan tanggung jawab yang ditanamkan kepada peserta didik. Sehingga peserta didik tumbuh menjadi anak yang berkarakter baik dalam beragama maupun bernegara.

\section{SIMPULAN}

Pendidikan karakter pada anak usia dini suatu hal yang sangat penting dilaksanakan. Anak-anak yang dididik di lembaga PAUD setidaknya menentukan tahap kehidupan selanjutnya terlebih dalam jenjang pendidikan. Karakter yang dibangun sejak usia dini merupakan cerminan bangsa kedepannya. Karakter anak akan dapat dibangun ketika dalam penanaman nilai karakter sesuai dengan kondisi anak itu sendiri atau karakter anak dapat dibangun sesuai dengan tumbuh kembang anak. Anak yang mempunyai hak untuk mendapatkan didikan sudah sepatutnya mendapat pendidikan terlebih karakter khususnya di lembaga PAUD.

KB Dewi Sartika Desa Batu Mak Jage memberikan bentuk pendidikan karakter melalui penanaman nilai karakter mempertimbangkan kondisi sosial masyarakat dan lingkungan tempat anak tinggal. Melalui proses pembelajaran yang dilakukan guru melakukan penanaman nilai karakter kepada anak. Setidaknya ada beberapa nilai karakter yang sangat penting dibangun kepada siswa di KB Dewi Sartika Desa Batu Mak Jage adalah: religi, jujur, peduli lingkungan, toleransi, peduli sosial, kerja sama, semangat kebangsaan, bersahabat, disiplin, rasa ingin tahu, dan demokratis. Penanaman nilai-nilai karakter yang dilakukan di KB Dewi Sartika sesuai dengan perkembangan anak usia dini.

\section{DAFTAR PUSTAKA}

Adib, Mohammad. 2012. Agen dan Struktur dalam Pandangan Pierre Bourdie. Jurnal BioKultur, Volume 2, Nomor 1.

Arif, Mahmud, dkk. 2013. Antologi Pendidikan Anak Usia Dini dan Pendidikan Dasar Islam. Yogyakarta: Pascasarjana UIN Sunan Kalijaga.

Asmawati, Luluk. 2014. Perencanaan Pembelajaran PAUD. Bandung: Remaja Rosdakarya. 
Jurnal PG-PAUD Trunojoyo : Jurnal Pendidikan dan Pembelajaran Anak Usia Dini, Volume 6, Nomor 2, Oktober 2019, hal $91-100$, ISSN : 2528-3553 (online), ISSN: 2407-4454 (print)

Fadillah, M. 2018. Buku Ajar Konsep Dasar PAUD. Ponorogo: Unmuh Ponorogo Press.

Inawati, Asti. 2017. Strategi Pengembangan Moral dan Nilai Agama Untuk Anak Usia Dini. Jurnal Al-Athfal: Jurnal Pendidikan Anak, Volume 3, Nomor 1.

Hamruni \& Syamsul Kurniawan, Political Education of Madrasah In The Historical Perspective, dalam jurnal SKIJIER, Volume 2, Nomor 2, 2018.

Hermansyah, Islam dan Melayu di Borneo, Pontianak: IAIN Pontianak Press, 2015.

Kurniawan, Syamsul \& Bayu Suratman, Bertani Padi dan Etos Kerja Petani Perempuan Dari Suku Melayu Sambas, dalam Raheema Jurnal Studi Gender dan Anak, Volume 6, Nomor 1, 2018.

Kurniawan, Syamsul, "Pantang Larang in the Sepinggan Village Community from the Perspective of Character Education, dalam Jurnal Ta'dib, Volume 2, Nomor 21, 2016.

Kurniawan, Syamsul, Pendidikan Karakter: Konsepsi \& Implementasinya Secara Terpadu di Lingkungan Keluarga, Sekolah, Perguruan Tinggi, \& Masyarakat. Yogyakarta: AR-RUZZ Media, 2013.

Kurniawan, Syamsul,dkk, Best Practice Character Building: Model, Inspirasi, dan Catatan Reflektif. Yogyakarta: Samudra Biru, 2019.

Lickona, Thomas, Pendidikan Karakter. Yogyakarta: Kreasi wacana, 2012.

Lickona, Thomas, Mendidik Untuk Membentuk Karakter: Bagaimana Sekoah Dapat Memberikan Pendidikan Tentang Sikap Hormat dan Bertanggung Jawab. Jakarta:Bumi Aksara, 2013.

Maemonah, Implementasi Pendidikan Karakter Di Madrasah/Sekolah, dalam jurnal Al-Bidayah: Jurnal Pendidikan Dasar Islam, Volume 7, Nomor 1, 2015.

Mahbubi.M, Pendidikan Karakter: Implementasi Aswaja Sebagai Nilai Pendidikan Karakter, Yogyakarta: Pustaka Ilmu, 2012.

Martin, Analisis Kecerdasan Interpersonal Anak Usia Dini Dan Implementasinya Dalam Bimbingan Dan Konseling, dalam jurnal Sosio Horizon: Jurnal Pendidikan Sosial, Voluime 3, Nomor 2, 2016.

Mardiyati, Isyatul, Penanaman Nilai-Nilai Dasar Islami Anak Usia Dini Pada Masyarakat Perkotaan. Jurnal AtTurats Volume 9, Nomor 1, 2015.

Mustari, Mohammad, Nilai Karakter Refleksi Untuk Pendidikan, Jakarta: Raja Grafindo Persada, 2014.

Mu'in, Fatchul, Pendidikan Karakter: Konstruksi Teoritik \& Praktik, Yogyakarta: Ar-Ruzz Media, 2016.

Mukodi, Mendialogkan Pendidikan Kita Sebuah Antologi Pendidikan. Yogyakarta: Magnum Pustaka Utama, 2011.

Muslich, Masnur, Pendidikan Karakter Menjawab Tantangan Krisis Multidimensional. Jakarta: Bumi Aksara, 2014.

Nadlifah, Revitalisasi Pendidikan Karakter Di PAUD Terpadu Aisyiah Nur'aini Yogyakarta, dalam jurnal Al-Athfal: Jurnal Pendidikan Anak, Volume 1, Nomor 2, 2015.

Nadlifah, Model Pembinaan Pendidikan Karakter Holistik Integratif di PAUD Terpadu An-Nur Sleman Yogyakarta, dalam jurnal Al-Athfal: Jurnal Pendidikan Anak, Volume 3, Nomor 1, 2017.

Prayitno \& Belferik Manulang. Pendidikan Karakter dalam Pembangunan Bangsa, Jakarta: Gramedia, 2011.

Racmawati, Yeni \& Euis Kurniati, Strategi Pengembangan Kreativitas Pada Anak Usia Taman Kanak-Kanak, Jakarta:Kencana, 2010.

Siti Musdah Mulia \& Ira D. Aini.(2013). Karakter Manusia Indonesia: ButirButir Pendidikan Karakter Generasi Muda, Bandung: Nuansa Cendekia.

Sudaryanti, Pentingnya Pendidikan Karakter bagi Anak Usia Dini, dalam jurnal Pendidikan Anak, Volume 1, Edisi 1, 2012.

Suyadi \& Maulidya Ulfah, Konsep Dasar PAUD. Bandung: Remaja Rosdakarya, 2013.

Ulfah, Maulidya, dkk, Implementasi Program Parenting dalam Menanamkan Nilai Moral Anak Usia Dini, dalam jurnal Indonesian Journal of Islamic Early 
100 Jurnal PG-PAUD Trunojoyo : Jurnal Pendidikan dan Pembelajaran Anak Usia Dini, Volume 6, Nomor 2, Oktober 2019, hal $91-100$, ISSN : 2528-3553 (online), ISSN: 2407-4454 (print)

Childhood Education, Volume 3, Nomor 2, 2018.

Veny Iswantiningtyas \& Widi Wulansari, Pentingnya Penilaian Pendidikan Karakter Anak Usia Dini, dalam Procceeding of the ICECRS, Volume 1, Nomor 3, 2018.

Wibowo, Agus, Pendidikan Karakter Usia Dini (strategi Membangun Karakter di Usia Emas), Yogyakarta: Pustaka Pelajar, 2017.

Wiyani, Novan Ardy, Bina Karakter Anak Usia Dini: Panduan Orangtua \& Guru dalam Membentuk Kemandirian \& Kedisiplinan Anak Usia Dini. Yogyakarta: AR-RUZZ Media, 2013.

Yusriadi, Identitas Orang Melayu di Hulu Sungai Sambas, dalam jurnal Khalustiwa, Volume 5, Nomor 1, 2015. Zulhijrah, Implementasi Pendidikan Karakter di Sekolah, dalam Jurnal Tadrib, Volume,1 Nomor, 1, 2015. 